\title{
ROLE OF NEWER MEDICAL EDUCATION TECHNOLOGIES AND ATTITUDE AND COMMUNICATION (AT-COM) MODULE IN TEACHING OTORHINOLARYNGOLOGY
}

\author{
Manpreet Singh Nanda ${ }^{1}$ \\ ${ }^{1}$ Associate Professor, Department of Otolaryngology Head and Neck Surgery, Maharishi Markandeshwar Medical College and Hospital, \\ Kumarhatti, Solan.
}

\begin{tabular}{l}
\hline ABSTRACT \\
BACKGROUND \\
Medical education is fast changing and there is a growing need to add attitude and communication skills to it. This study aims to \\
study the acceptability of newer technologies of teaching and assessment and attitude and communication module to install basic \\
knowledge, skill and attitude towards learning among students. This study also aimed to study the existing methods of assessment \\
in ENT, their strengths and weaknesses.
\end{tabular}

\section{MATERIALS AND METHODS}

Students of MBBS III year, Batch 2013 and 2014 of our medical college and hospital were exposed to newer methods of learning and evaluation in Otorhinolaryngology like small group learning, large group learning and Objective Structured Clinical Examination and their impact was analysed. Review of last 10 years MBBS ENT question papers of various Indian universities was also done.

\section{RESULTS}

The newer methods of teaching and assessment were found more acceptable among the students of both batches and it increased their interest in learning Otorhinolaryngology. Most of the previous question papers lacked the coverage of whole syllabus with more focus on certain topics and certain type of questions.

\section{CONCLUSION}

There is a need to improve our medical education to develop a more competent and responsive medical practitioner for betterment of our society.

\section{KEYWORDS}

Attitude, Communication, Competence, Teaching, Otorhinolaryngology.

HOW TO CITE THIS ARTICLE: Nanda MS. Role of newer medical education technologies and attitude and communication (ATCOM) module in teaching otorhinolaryngology. J. Evolution Med. Dent. Sci. 2017;6(90):6301-6303, DOI: 10.14260/jemds/2017/1370

\section{BACKGROUND \\ Otorhinolaryngology, also known as Ear, Nose and Throat (ENT) and recently as Otolaryngology and Head and Neck Surgery, is an important part of health care and so is an important part of MBBS curriculum. But it has not achieved its full potential in our country. Advances in educational technology can lead to its upliftment. There is a need to develop newer educational innovations that may improve ENT teaching in our medical colleges. \\ The current state of teaching ENT at MBBS level needs to be uplifted to train basic physicians at Primary Health Care (PHC) level. It is this PHC level care which needs to be improved in the interest of our society. ENT is both a clinical as well as surgical branch. Observing and performing basic skills in ENT is necessary for medical trainees. ${ }^{[1]}$ The existing methods of teaching and assessing ENT needs to be reformed to develop a competent, committed medical practitioner who is skilled, responsive, committed to his patients and can communicate well.}

'Financial or Other Competing Interest': None.

Submission 05-09-2017, Peer Review 07-11-2017,

Acceptance 13-11-2017, Published 20-11-2017.

Corresponding Author:

Dr. Manpreet Singh Nanda,

H. No. 554

Sector-36 B,

Chandigarh.

E-mail: u_tell_me_80@yahoo.co.in

DOI: $10.14260 /$ jemds $/ 2017 / 1370$
Till now MBBS education focussed on one domain of learning - cognitive (head) and rarely on psychomotor (hand) and rarest on affection and attitude (heart).[2] There was no emphasis on communication skills. So the concept of holistic health care is missing.[3] This has led to increased mistrust among public for doctors and increased violence against doctors due to negligence, unethical behaviour and lack of communication.[4] So there is a need to add ethics, attitude and communication to our ENT teaching at MBBS level.

So, this study was planned to study the acceptability of newer technologies of teaching and assessment and attitude and communication module to instil basic knowledge, skill and attitude towards learning among students. This study also aimed to study the existing methods of assessment in ENT, their strengths and weaknesses and to suggest newer methods of learning and assessment.

\section{MATERIALS AND METHODS}

This study was conducted in Department of ENT of our medical college and hospital from June 2016 to June 2017 after obtaining approval from local ethics committee. MBBS III year students Batch 2013 and 2014 studying ENT in our medical college and hospital were exposed to newer teaching methodologies like Objective Structured Clinical Examination (OSCE), small group discussions and large group discussions. Their response to these teaching methods was analysed. These methodologies were adopted for 1 year. Analysis of 10 
years previous MBBS ENT question papers of various reputed Indian universities was done.

OSCE - It was used as an assessment tool. 8 to 10 stations of equal time were made and marks were allotted. Some of them were observed stations with checklist to assess the skills (performing a procedure or test) and to assess attitude and communication skills. Remaining were unobserved stations with questions to check knowledge.

Small group learning - This was done for small group of 15 students posted for clinics. They were divided into 3 groups of 5 each named $\mathrm{A}, \mathrm{B}$ and $\mathrm{C}$ and each group was given one different topic to read for 30 minutes. Then these group students were furthered labelled as $1,2,3,4$ and 5 (A1, A2, A3, A4, A5, B1, B2, B3, B4, B5, C1, C2, C3, C4, C5). Now the groups were redesigned. All $1-\mathrm{AI}, \mathrm{B} 1, \mathrm{C} 1$ made group I, 2 A2, B2, C2 made group II, 3 - A3, B3, C3 made group III, 4 A4, B4, C4 made group IV and 5 - A5, B5, C5 made group V. So all these new groups had one student each of previous group and each student taught his earlier discussed topic to others for 10 minutes each. Hence, all 3 topics were discussed among all with active participation of all. At last all these 5 groups I, II, III, IV and V had to select one group leader and a speaker who would discuss the topic with the teacher.

Large group learning - This was done during seminars for a large batch of around 150 students. Five students were asked to prepare a topic before seminar. The class was divided into batches $\mathrm{A}, \mathrm{B}, \mathrm{C}, \mathrm{D}$ and $\mathrm{E}$ of 30 each. All the five students were asked to teach the small batch of 30 on rotation basis for 10 minutes each. After 50 minutes of initial teaching, all the 5 groups were asked to select a group leader and a speaker who were asked to speak about a topic taught earlier in front of teacher. Thus, a large seminar class was made into small class of 30 with active participation of all students.

Analysis of Previous 10 Years ENT MBBS Question Papers of Various Indian Universities was done and following things were studied -

1. Coverage of all topics - Ear, Nose, Pharynx, Larynx, Oral cavity including salivary glands, Neck including thyroid gland.

2. Coverage of all type of questions - clinical procedure/test, surgeries, basic sciences, diseases, recent advances.

3. Whether the paper included long notes, short notes, short answers and multiple choice questions (MCQ).

For calculating the percentage of marks for each type of question, the average of the question papers of all the universities was taken.

\section{RESULTS}

OSCE as a method of assessment was found better and more acceptable for both batches. (Table 1). Students of both batches found small group teaching to be a better way of teaching than the traditional one way discussion by teacher in ENT clinics. All of them equally participated in both teaching and learning and benefited from this method. (Table 2).

Both batch students found this large group teaching method of conducting seminars better than the traditional seminars where one student used to speak in front of entire class and didn't involve most of students. (Table 3).
Regarding analysis of previous question papers, most of the papers were focussed on ear and nose diseases giving less importance to other topics. (Table 4). Most of the papers focussed on long essays and short essays, very few on short answers and almost none on MCQ. (Table 5). Most of the papers had questions on diseases and surgeries and very few on clinical tests and procedures and recent advances. (Table 6).

\begin{tabular}{|c|c|c|}
\hline & Batch 2013 & Batch 2014 \\
\hline Better & $70 \%$ & $68 \%$ \\
\hline Same & $20 \%$ & $24 \%$ \\
\hline Worse & $10 \%$ & $08 \%$ \\
\hline
\end{tabular}

Table 1. Acceptability of OSCE Among Students (As Compared to Traditional Methods of Assessment)

\begin{tabular}{|c|c|c|}
\hline & Batch 2013 & Batch 2014 \\
\hline Better & $80 \%$ & $88 \%$ \\
\hline Same & $15 \%$ & $10 \%$ \\
\hline Worse & $05 \%$ & $02 \%$ \\
\hline
\end{tabular}

Table 2. Acceptability of Small Group Teaching among Students (As Compared to Traditional Methods of Teaching)

\begin{tabular}{|c|c|c|}
\hline & Batch 2013 & Batch 2014 \\
\hline Better & $58 \%$ & $61 \%$ \\
\hline Same & $28 \%$ & $30 \%$ \\
\hline Worse & $14 \%$ & $09 \%$ \\
\hline
\end{tabular}

Table 3. Acceptability of Large Group Teaching among Students (As Compared to Traditional Methods of Seminars)

\begin{tabular}{|c|c|c|}
\hline Topic & $\begin{array}{c}\text { Average \% of } \\
\text { Marks in Last 10 } \\
\text { Years Papers }\end{array}$ & $\begin{array}{c}\text { \% of Marks in an } \\
\text { Ideal Standard } \\
\text { Paper }\end{array}$ \\
\hline Ear & $38 \%$ & $30 \%$ \\
\hline Nose & $27 \%$ & $20 \%$ \\
\hline Larynx & $15 \%$ & $15 \%$ \\
\hline Pharynx & $13 \%$ & $10 \%$ \\
\hline $\begin{array}{c}\text { Oral cavity } \\
\text { including salivary } \\
\text { glands }\end{array}$ & $05 \%$ & $10 \%$ \\
\hline $\begin{array}{c}\text { Neck including } \\
\text { thyroid glands }\end{array}$ & $02 \%$ & $15 \%$ \\
\hline
\end{tabular}

Table 4. Analysis of Previous ENT Question Papers - Topics Division as Compared to Ideal Question Paper

\begin{tabular}{|c|c|c|}
\hline Type & $\begin{array}{c}\text { Average \% of Marks in } \\
\text { Last 10 Years Papers }\end{array}$ & $\begin{array}{c}\text { \% of Marks in an } \\
\text { Ideal Standard Paper }\end{array}$ \\
\hline Long notes & $33 \%$ & $25 \%$ \\
\hline Short notes & $51 \%$ & $25 \%$ \\
\hline $\begin{array}{c}\text { Short } \\
\text { answers }\end{array}$ & $15 \%$ & $25 \%$ \\
\hline MCQ & $01 \%$ & $25 \%$ \\
\hline
\end{tabular}

Table 5. Analysis of Previous ENT Question Papers - Type of Questions as Compared to Ideal Question Paper 


\begin{tabular}{|c|c|c|}
\hline Nature & \begin{tabular}{|c|} 
Average $\%$ of \\
marks in last \\
10 years papers
\end{tabular} & $\begin{array}{c}\% \text { of marks in } \\
\text { an ideal } \\
\text { standard paper }\end{array}$ \\
\hline Diseases & \begin{tabular}{|l|}
$56 \%$ \\
\end{tabular} & $25 \%$ \\
\hline Surgeries & $25 \%$ & $20 \%$ \\
\hline $\begin{array}{l}\text { Anatomy and physiology } \\
\text { (Basic Sciences) }\end{array}$ & $15 \%$ & $25 \%$ \\
\hline $\begin{array}{l}\text { Clinical tests and } \\
\text { procedures }\end{array}$ & $02 \%$ & $15 \%$ \\
\hline Recent advances & $02 \%$ & $15 \%$ \\
\hline
\end{tabular}

\section{DISCUSSION}

In our country, around 60000 MBBS graduates pass out every year. But at present at PHC level, these graduates have poor confidence level in practising and managing patients especially related to ENT. This has led to higher burden on fewer higher centres in cities and delayed and neglected treatment. The flaw lies in the undergraduate ENT teaching, curriculum and assessment.

Miller's prism of clinical competence also known as Miller's pyramid focuses on all four parameters - knowledge, skill, attitude and communication.[3] But our present teaching and assessment is mainly focussed on knowledge part with little focus on skill and almost none on attitude and communication. For the same purpose, Medical Council of India (MCI) has focussed on attitude, communication and ethics which is known as Attitude and Communication (ATCOM) Module.[5] There is a growing need for competency based curriculum. Important component of the same is team work - where people work together for a specific purpose and here it is learning or self-directed learning. Tuckman in 1965 designed four stages of team development - forming, storming, norming and performing.[6] In our study, the concept of small group learning and large group learning was based on same, which students found to be more interesting and a better way of learning with active participation from all (Table 2 and 3). Similar studies were done earlier on small groups by Jaques D[7] and on large groups by Cantillon P.[8]

Assessment is the way to establish if the learning has taken place. The ideal assessment should be valid - all domains should be tested, unbiased, objective and feasible. For clinical skills, the present way of assessment is long case and short case in ENT. But this assessment is very subjective i.e. it is examiner dependent - on his mood or prejudice or case dependent - easy or tough, uncooperative patient. The assessment is also knowledge based. No skill, attitude or communication is tested. Most of the time students take the case when examiner is busy in paper correction or tea/coffee and present it to the examiner. On the other hand, OSCE can test all domains, is objective, nonbiased and takes less time, so more acceptable. In our study also, we found OSCE to be more acceptable (Table 1). OSCE was also found to be better way of assessment in other studies by Newble in 2004[9] and Harden et al.[10]

In our study, we found newer technologies like small and large group teaching promote more communication by ways of group learning and increased interaction among students. This will definitely improve the communication and attitude domains of MBBS graduates. Assessment methods like OSCE assess the attitude, skills and communication domains along with knowledge. These newer technologies hence can help in improving attitude and communication skills.

Regarding theory papers in ENT, we found disproportionate covering of whole syllabus (Table 4). There was also disproportionate covering of all required skills in theory paper (Table 6). The assessment was more subjective than objective (Table 5). The author suggests equal distribution of marks among whole syllabus (Table 4), coverage of all type of questions including clinical based and recent advances (Table 6) and more weightage to objective type of questions like MCQ and short answers (Table 5) to make the assessment more ideal and valid.

\section{CONCLUSION}

There is a need to improve our medical education to develop a more competent and responsive medical practitioner for betterment of our society. The need is to make the education outcome based with more focus on ethics, attitude and communication. There is a need for team study and selfdirected study. Newer educational innovations like OSCE, small group and large group teaching are a step towards that goal especially in a branch like ENT where there is a need to develop some skills, attitude and communication along with knowledge domain at MBBS level. This will be a big step towards better primary health care in our country.

\section{ACKNOWLEDGMENTS}

I would like to thank my medical college and hospital and department of ENT for its support and the students for active participation and interest in learning and assessment methods.

\section{REFERENCES}

[1] Dawson SL. A critical approach to medical simulation. Bull Am Coll Surg 2002;87(11):12-8.

[2] Modi JN, Gupta P, Singh T. Competency-based medical education, entrustment and assessment. Indian Pediatr 2015;52(5):413-20.

[3] Kumar R. Medical education in India: an introspection. Indian J Public Adm 2014;60(1):146-54.

[4] Vinodkumar CS, Kalasuramath S, Kumar CS, et al. The need of attitude and communication competencies in medical education in India. J Educ Res Med Teacher 2015;3(1):1-4.

[5] Mitra J, Saha I. Attitude and communication module in medical curriculum: rationality and challenges. Indian J Public Health 2016;60(2):95-8.

[6] Tuckman BW, Jensen MAC. Stages of small group development revisited. Group and Organizational Management 1977;2:419-27.

[7] Jaques D. Teaching small groups. BMJ 2003;326(7387):492-4.

[8] Cantillon P. Teaching large groups. BMJ 2003;326(7386):437.

[9] Newble D. Techniques for measuring clinical competence: objective structured clinical examinations. Med Educ 2004;38(2):199-203.

[10] Harden RM, Stevenson M, Downie WW, et al. Assessment of clinical competence using objective structured examination. Br Med J 1975;1(5955):44751. 